\title{
The Constancy of the $\alpha_{1}$-Acid Glycoprotein Variants of Normal Adults under Conditions of Severe Stress *
}

\author{
K. Tokita, $\dagger$ J. F. Burke, H. Yoshizaki, $\uparrow$ Suzanne Fischer, and \\ K. SCH MID $\ddagger$ \\ (From the Department of Biochemistry, Boston University School of Medicine, Boston \\ University Medical Center, and the Department of Surgery, Massachusetts General \\ Hospital and Harvard Medical School, Boston, Mass.)
}

The nonspecific increase in the blood level of $\alpha_{1-}$ acid glycoprotein (orosomucoid) and other plasma proteins observed in many unrelated disease states has been documented and reviewed repeatedly $(1-5) .^{1}$ Evidence has been presented that the increase of the $\alpha_{1}$-acid glycoprotein ${ }^{2}$ is due to an augmented biosynthesis (9), which in turn is a consequence of the increased formation of the corresponding specific messenger RNA (10). The structure of this glycoprotein, however, has been assumed to be unchanged. Recently, it was shown that $\alpha_{1}$-acid glycoprotein reveals three types of variant patterns, and the variants appear to be genetically controlled (11). The determination of certain aspects of the structure of this protein derived from normal individuals, namely the sialic acid content and the type of its variants before, during, and after a period of considerable stress, should provide support for the genetic control of the structure of $\alpha_{1}$-acid glycoprotein.

* Submitted for publication March 21, 1966; accepted July 7, 1966.

This investigation was supported by U. S. Public Health Service research grants GM-10374, 1-K3-GM32,160-01, and AI-2392 from the National Institutes of Health, Division of General Medical Sciences and the National Institute of Allergy and Infectious Diseases.

A preliminary note on part of this study was published in Fed. Proc. 1965, 24, 469.

$\dagger$ Recipient of a travel fellowship from the Japanese Ministry of Education, Tokyo.

¥ Address requests for reprints to Dr.-Karl Schmid, Dept. of Biochemistry, Boston University School of Medicine, 80 E. Concord St., Boston, Mass. 02118.

1 References 1-5 list earlier reviews of this subject.

$2 \alpha_{1}$-Acid glycoprotein, a constituent of normal human plasma, has been prepared in the homogeneous state as judged by classical criteria of purity $(6-8)$. It contains $11 \%$ sialic acid, $15 \%$ neutral hexoses, $14 \%$ glucosamine, $1 \%$ fucose, and $60 \%$ amino acid residues (6-8). The half-life of this glycoprotein is about 5.5 days (10).
In the present study $\alpha_{1}$-acid glycoprotein, isolated from apparently normal adults who underwent major surgical procedures and from women during pregnancy and after delivery, was analyzed for the type of its variant and for its sialic acid content.

\section{Methods}

Three groups of apparently healthy adults donated blood for this investigation. Blood (20 to $40 \mathrm{ml}$ ) was taken by venipuncture under sterile conditions and was permitted to clot. The serum was separated, shell frozen, and stored at $-40^{\circ} \mathrm{C}$ until fractionated. $A$ ) Four Caucasian laboratory workers, age 21 to 45 (three male and one female), served as controls. From these individuals blood specimens were taken every month for 6 months. $B$ ) Blood was also taken from six apparently healthy Caucasian adults who underwent major surgery (Table II). The blood was obtained shortly after operation and again between 4 days and 5 weeks thereafter. These individuals varied in age between 63 and 89 years. C) The third group included seven apparently healthy pregnant Japanese of the Sendai area from whom blood was obtained during the latter part of their pregnancy and after delivery.

The obtained sera amounting to 13 to $22 \mathrm{ml}$ were fractionated by a modification of Cohn methods 6 and 10 $(11,12)$. The resulting Fractions VI were chromatographed on Amberlite IRC-50 (12, 13). The isolated, homogeneous $\alpha_{1}$-acid glycoprotein preparations were treated with Clostridium perfringens neuraminidase (14) and then analyzed by starch gel electrophoresis at $\mathrm{pH} 5$ $(11,12)$. In control experiments using normal pooled $\alpha_{1}$-acid glycoprotein it could be demonstrated that over $99 \%$ of the sialic acid was cleaved off and that on starch gel electrophoresis the expected patterns were obtained (11).

The seromucoid fraction was determined by the perchloric acid-phosphotungstic acid procedure described by Winzler (15) using $3.0 \mathrm{ml}$ of serum. The hexose and the polypeptide content of this fraction was measured by the orcinol and biuret techniques, respectively (15). Sialic acid was measured by the Warren (16) and Svennerholm (17) methods. For the latter determina- 
tion about $1 \mathrm{mg}$ of $\alpha_{1}$-acid glycoprotein was dissolved in $1 \mathrm{ml}$ of water. The protein concentration was obtained by dividing the absorbancy at $278 \mathrm{~m} \mu$ by the extinction coefficient of 8.93 of this protein (6). Paper electrophoresis of the sera was carried out in $\mathrm{pH} 8.6, \Gamma / 20.1$ citrate-diethylbarbiturate buffer. Horizontal starch gel electrophoresis in $\mathrm{pH} 8.6$ borate buffer was performed according to Smithies (18) and double diffusion according to Ouchterlony (19).

\section{Results}

A) Normal Caucasian adults as controls. The patterns of $\alpha_{1}$-acid glycoprotein variants of the four normal Caucasian adults remained unchanged over the period studied (Table I). Two individuals revealed type III and one type II and one type I. The sialic acid content of the three $\alpha_{1}$-acid glycoprotein types was the same and remained constant for all individuals.

B) Normal Caucasian adults who underwent major operations. The type of $\alpha_{1}$-acid glycoprotein variant of each patient undergoing operation remained the same over the period of investigation (Table II). One individual had a type I pattern, two showed type II patterns, and four revealed type III patterns. The sialic acid content of the isolated $\alpha_{1}$-acid glycoprotein preparations was always $11 \%$ (allowing for error of the method). For some of these individuals, the $\alpha_{1}$-acid glycoprotein preparations were analyzed at $\mathrm{pH} 8.6$ by paper and starch gel electrophoresis and revealed homogeneity, confirming our earlier finding (11). In Figure 1, typical starch gel electrophoretic patterns of a pre- and postoperative $\alpha_{1}$-acid glycoprotein sample are shown, indicating that these protein preparations reveal the same apparent electrophoretic mobilities as pooled normal $\alpha_{1}$-acid

TABLE I

Constancy of the type and composition of $\alpha_{1}$-acid glycoprotein variants of normal Caucasian adults

\begin{tabular}{|c|c|c|c|c|c|c|c|c|}
\hline \multirow[b]{3}{*}{ Sample } & \multicolumn{8}{|c|}{ Variant (type) and sialic acid content (\%) } \\
\hline & \multicolumn{2}{|c|}{ SK* } & \multicolumn{2}{|c|}{ NR* } & \multicolumn{2}{|c|}{ MA* } & \multicolumn{2}{|c|}{$\mathrm{HK}^{*}$} \\
\hline & Type & $\%$ & Type & $\%$ & Type & $\%$ & Type & $\%$ \\
\hline 1 & I & 10.8 & II & 10.7 & III & 11.0 & III & 10.9 \\
\hline 2 & I & 10.7 & II & 10.2 & III & 11.0 & III & 10.4 \\
\hline 3 & I & 10.7 & II & 10.4 & III & 10.8 & III & 11.1 \\
\hline 4 & $\mathrm{I}$ & 10.1 & II & 10.0 & III & 11.1 & III & 10.8 \\
\hline 5 & I & 11.1 & II & 10.4 & III & 11.0 & III & 11.0 \\
\hline 6 & I & 10.8 & II & 10.1 & III & 10.0 & III & 10.4 \\
\hline
\end{tabular}

* Initials of individuals studied.

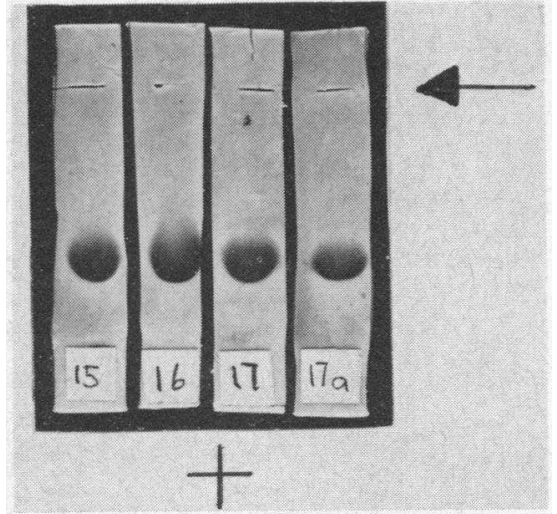

Fig. 1. Starch gel electrophoresis of $\alpha_{1}$-ACid glycoPROTEIN PREPARATIONS DERIVED FROM SERUM OF A NORMAL ADUlt (WJ) BEFORE (No. 15) AND 13 (No. 16) AND 21 (No. 17) DAYS AFTER ARTERIAL GRAFT OPERATION. The slots of application are indicated by the arrow and the direction of migration by the plus sign. Amido black 10B was utilized as stain. As control (no. 17a) pooled $\alpha_{1-}$ acid glycoprotein was used.

glycoprotein. As about equal amounts of protein were applied in each analysis, the color intensity of each protein band appeared about the same. Immunochemical analysis (Figure 2) demonstrated identity of the $\alpha_{1}$-acid glycoprotein formed

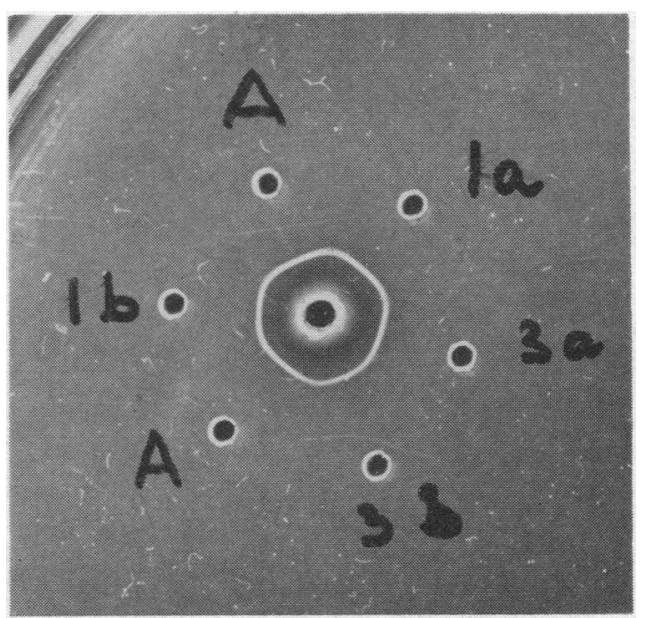

Fig. 2. OUChterlony Double-diffusion analysis of $\alpha_{1}$-ACID GLYCOPROTEIN OF TWO APPARENTLY NORMAL ADULTS BEFORE (NO. 1A AND 3A) AND AFTER HIP OPERATION (NO. 1B AND 3B). As control (A) pooled normal $\alpha_{1}$-acid glycoprotein was used. The center well contained rabbit serum active against pooled normal $\alpha_{1}$-acid glycoprotein. The agar was dissolved in $\mathrm{pH} 8.6, \Gamma / 20.1$ borate and the protein in $0.9 \% \mathrm{NaCl}$ to give a concentration of $0.1 \%$. The photograph was taken after an incubation time of 1 day at room temperature. 
TOKITA, BURKE, YOSHIZAKI, FISCHER, AND SCHMID

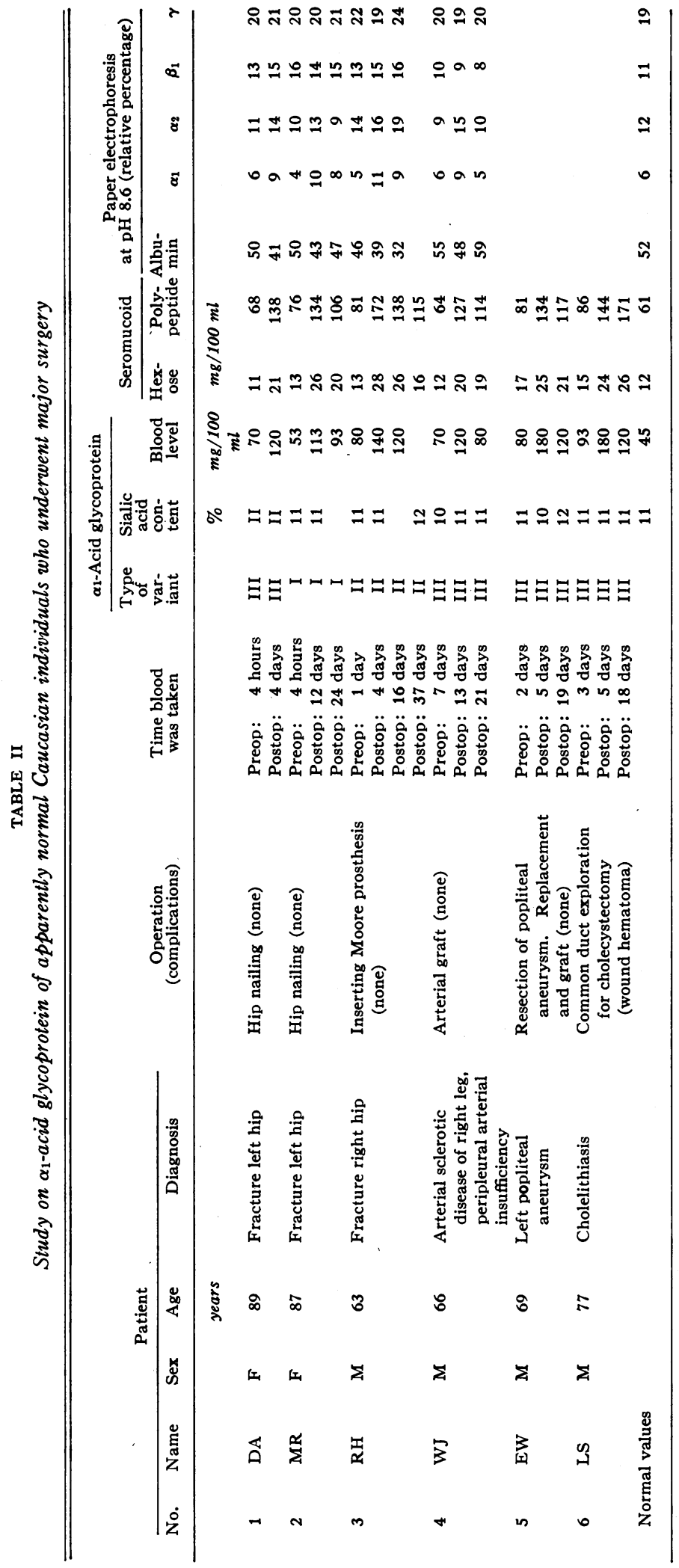


TABLE III

Study on $\alpha_{1}$-acid glycoprotein, seromucoid fractions, and electrophoretic distribution of the serum protein of pregnant Japanese women

\begin{tabular}{|c|c|c|c|c|c|c|c|c|c|c|c|c|c|c|}
\hline \multirow[b]{3}{*}{ No. } & \multirow[b]{3}{*}{ Name } & \multirow[b]{3}{*}{ Age } & & & \multicolumn{3}{|c|}{$\alpha 1$-Acid glycoprotein } & \multirow{2}{*}{\multicolumn{2}{|c|}{ Seromucoid }} & \multirow{2}{*}{\multicolumn{5}{|c|}{$\begin{array}{c}\text { Paper electrophoresis at pH } 8.6 \\
\text { (relative percentage) }\end{array}$}} \\
\hline & & & & & Type & Sialic & & & & & & & & \\
\hline & & & \multicolumn{2}{|c|}{$\begin{array}{l}\text { Time blood } \\
\text { was taken }\end{array}$} & $\begin{array}{l}\text { var- } \\
\text { iant }\end{array}$ & $\begin{array}{l}\text { con- } \\
\text { tent }\end{array}$ & $\begin{array}{l}\text { Blood } \\
\text { level }\end{array}$ & $\begin{array}{l}\text { Hex- } \\
\text { ose }\end{array}$ & $\underset{\text { peptide }}{\text { Poly- }}$ & $\underset{\mathrm{min}}{\text { Albu- }}$ & $\alpha_{1}$ & $\alpha_{2}$ & $\beta_{1}$ & $\gamma$ \\
\hline & & years & & & & $\%$ & $\begin{array}{c}\mathrm{mg} / \\
100 \mathrm{ml}\end{array}$ & \multicolumn{2}{|c|}{$\mathrm{mg} / 100 \mathrm{ml}$} & & & & & \\
\hline \multirow[t]{3}{*}{11} & $\mathbf{M H}$ & 29 & Prepart: 1 & 106 days & II & 11 & 25 & 9 & 55 & 49 & 7 & 12 & 15 & 17 \\
\hline & & & Prepart: & 15 days & II & 12 & 53 & 12 & 55 & 42 & 9 & 7 & 19 & 23 \\
\hline & & & Postpart: & 1 day & II & 12 & 76 & 14 & 64 & 42 & 9 & 10 & 21 & 18 \\
\hline \multirow[t]{2}{*}{12} & MS & 24 & Prepart: & 73 days & II & 11 & 44 & 8 & 46 & 47 & 9 & 10 & 14 & 20 \\
\hline & & & Postpart: & 1 hour & II & 12 & 60 & 12 & 57 & 44 & 7 & 14 & 15 & 20 \\
\hline \multirow[t]{3}{*}{13} & KO & 20 & Prepart: & 85 days & II & 12 & 36 & 8 & 45 & 53 & 7 & 10 & 12 & 18 \\
\hline & & & Prepart: & 15 days & II & 10 & 50 & 8 & 40 & 40 & 9 & 8 & 18 & 23 \\
\hline & & & Postpart: & 4 days & II & 12 & 78 & 13 & 74 & 40 & 7 & 17 & 15 & 21 \\
\hline \multirow[t]{2}{*}{14} & YS & 31 & Prepart: & 68 days & I & 10 & 25 & 6 & 43 & 48 & 6 & 8 & 18 & 20 \\
\hline & & & Postpart: & 4 days & I & 12 & 40 & 12 & 82 & 41 & 9 & 13 & 18 & 19 \\
\hline \multirow[t]{2}{*}{15} & $\mathbf{H H}$ & 24 & Prepart: & 68 days & II & 11 & 55 & 9 & 55 & 37 & 5 & 13 & 18 & 27 \\
\hline & & & Postpart: & 3 days & II & 11 & 82 & 14 & 80 & 38 & 11 & 12 & 18 & 21 \\
\hline \multirow[t]{3}{*}{16} & KO & 29 & Prepart: & 46 days & II & 10 & 24 & 6 & 36 & 42 & 9 & 14 & 18 & 17 \\
\hline & & & Prepart: & 10 days & II & 11 & 78 & 13 & 66 & 35 & 8 & 15 & 22 & 20 \\
\hline & & & Postpart: & 5 days & II & 11 & 139 & 18 & 104 & 41 & 9 & 16 & 15 & 20 \\
\hline \multirow[t]{3}{*}{17} & $\mathrm{KA}^{*}$ & 27 & Prepart: & 69 days & I & & 29 & 8 & 48 & 48 & 8 & 10 & 16 & 18 \\
\hline & & & Prepart: & $\frac{1}{3}$ hour & I & 10 & 39 & 9 & 47 & 46 & 9 & 12 & 15 & 18 \\
\hline & & & Postpart: & 6 days & I & 11 & 121 & 22 & 119 & 42 & 9 & 15 & 16 & 18 \\
\hline
\end{tabular}

* Caesarian delivery.

before and after operation as judged by the complete fusing of the formed precipitin lines. With regard to the seromucoid and $\alpha_{1}$-acid glycoprotein levels, we noted that the preoperative seromucoid levels of four individuals were slightly elevated, probably as a result of the nonspecific stress reaction of a recent fracture, gallstones, or aneurysm. None of these patients, however, showed clinical evidence of systemic disease. Two of the individuals studied had normal preoperative seromucoid levels.

The increase of the seromucoid fractions of all blood specimens taken after operation was significant and was at least double the normal value (1). The blood level of these fractions decreased at a slow rate thereafter. Even after 37 days the normal value had not yet been obtained (No. 3, Table II). The change in the blood concentration of $\alpha_{1}$-acid glycoprotein and of the total electrophoretically separated $\alpha_{1}$ - and $\alpha_{2}$-globulins showed a similar course. Only two individuals (No. 1 and No. 2) showed normal preoperative levels of these components. Patient 6 , who developed a wound hematoma, revealed, in the second postoperative analysis, an even further increase in the mentioned blood levels. Paper electrophoretic analysis of the sera taken immediately after operation demon- strated a considerable increase in $\alpha_{1}$ - and $\alpha_{2}$-globulins and a corresponding decrease in the relative concentration of albumin, whereas the level of the $\gamma$-globulins remained essentially constant.

C) Japanese pregnant women. The type of $\alpha_{1}$ acid glycoprotein variant of each individual remained constant over the period of analysis. Two

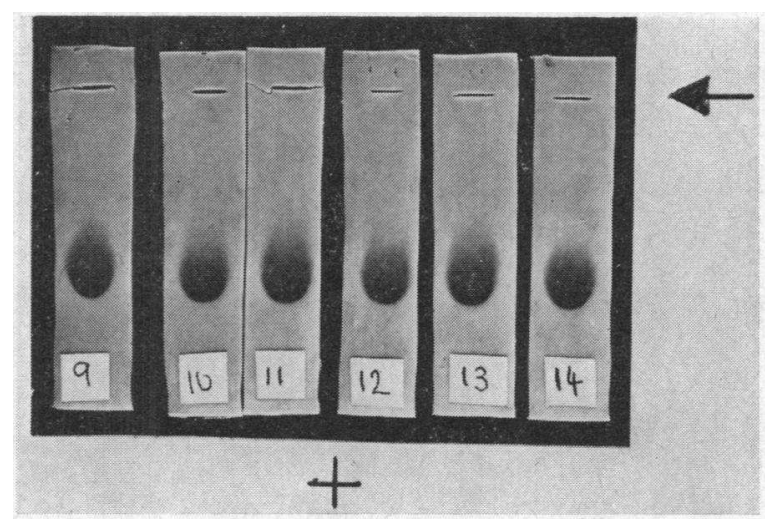

Fig. 3. StarCh gel ELECTROPHORETIC ANALYSIS OF $\alpha_{1}$ ACID GLYCOPROTEIN DERIVED FROM TWO PREGNANT WOMEN (MS AND YS) BEFORE (No. 10 AND 12) AND AFTER (No. 11 AND 13) DELIVERY. The slot of application is indicated by the arrow and the direction of migration by the plus sign. As control (no. 9 and 14) pooled $\alpha_{1}$-acid glycoprotein was used. 


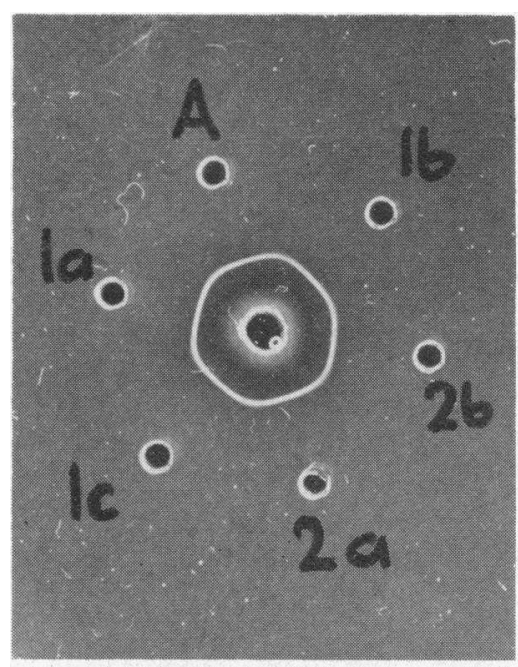

Fig. 4. OUChterlony Double-diffusion analysis of $\alpha_{1}$-ACID GLYCOPROTEIN OF TWO JAPANESE WOMEN ( $\mathrm{MH}$ AND MS) BEFORE (NO. 1A AND 2A) AND AFTER (1B, 1C, AND 2B) DELIVERY. Pooled normal $\alpha_{1}$-acid glycoprotein was used as control. A rabbit serum active against pooled normal $\alpha_{1}$-acid glycoprotein was placed in the center well. The protein was dissolved in $0.9 \% \mathrm{NaCl}$ to give a concentration of $0.1 \%$.

individuals showed type I and the others type II (Table III). The high incidence of type II in this group is to be expected from earlier studies, in contrast to the types found for the Caucasians, among whom type III is predominant (11). The blood levels of $\alpha_{1}$-acid glycoprotein of these individuals increased up to threefold over the normal. Taking into consideration the error of the method used, the sialic acid content of the isolated protein preparations was determined to be $11 \%$. Starch gel electrophoresis of the pre- and postpartum $\alpha_{1}$-acid glycoprotein preparations showed homogeneity and the same electrophoretic migration rate (Figure 3). On double diffusion analysis (Figure 4) these protein preparations formed precipitin lines that fused completely with each other and with that of pooled $\alpha_{1}$-acid glycoprotein.

The changes in the blood level of $\alpha_{1}$-acid glycoprotein and of the seromucoid fraction are divided into two parts: One part covers the period of pregnancy and the other the period after delivery. During pregnancy a gradual rise in these two parameters was noted. This could be observed particularly well in the case of individuals No. 1, 2, 3, and 6. It should be noted, however, that the reaction of these patients towards preg- nancy, as measured by the level of $\alpha_{1}$-acid glycoprotein and the seromucoid fraction, differs from one to another. However, all individuals showed elevations between 50 and $100 \%$ above normal at term, and an additional increase was noted 3 to 4 days after delivery. A special case is represented by No. 17, who had a Caesarian operation. This patient showed a very high increase in the level of $\alpha_{1}$-acid glycoprotein and of the seromucoid fraction. Paper electrophoresis of the sera of this series of analyses did not reveal any pertinent findings although there were changes in the $\alpha_{1}^{-}, \alpha_{2}^{-}$, and $\beta$-globulin concentrations.

\section{Discussion}

The major finding of the present study is the constancy of the type of the $\alpha_{1}$-acid glycoprotein variants found in individuals whose blood level of this protein increased greatly over a limited period of time as a reaction to the stress of major surgery or pregnancy and especially delivery. It has been shown that in such states the half-life of $\alpha_{1}$-acid glycoprotein is probably normal and independent of its blood level. In the patients studied, therefore, the biosynthesis and catabolism of this protein must have been considerably increased to account for the elevated level of the mentioned protein (10). Further, the present investigation demonstrates that the $\alpha_{1}$-acid glycoprotein produced at any of the blood levels investigated maintains its chemical composition and structure. The sialic acid content, selected as index of the normal chemical composition because of its terminal position on the oligosaccharide chains, remains constant and equal to that formed in the normal state. More important, the structure of this protein is also maintained; the type of variant remains constant and independent of the change and of the level in the blood concentration of this protein. Further, these $\alpha_{1}$-acid glycoprotein preparations appeared homogeneous on starch gel electrophoresis at $\mathrm{pH} 8.6$ and revealed electrophoretic mobilities indicative of the same electrostatic net charge. In addition, they shared the same immunochemical determinants. The constancy of the variant and of the chemical composition of $\alpha_{1}$-acid glycoprotein of each individual serves as considerable evidence in support of the concept of a genetically determined structure of $\alpha_{1}$-acid glycoprotein. 
The increase in the $\alpha_{1}$-acid glycoprotein level after the stress of operation could not be observed until 4 to 7 days thereafter, agreeing with comparable reports of others $(1,10,20-23)$. As the length of pregnancy increased, the $\alpha_{1}$-acid glycoprotein and seromucoid level generally increased as has been reported earlier (24-26). The additional increase in these values after delivery also agrees with previous findings $(24,27)$. The decrease to normal $\alpha_{1}$-acid glycoprotein levels may take several weeks and is associated with the rate at which the patient returns to a normal state of health.

The increase in the $\alpha_{1}$-acid glycoprotein blood level, nonspecific in nature and often referred to as a phase reactant $(2,28)$, has usually been measured indirectly by determining the concentration of seromucoid fractions $(15,29)$ and occasionally by immunochemical analysis (30-32). In the present study, the blood concentration of $\alpha_{1}$-acid glycoprotein was measured for the first time directly by isolating this protein from the serum. As $\alpha_{1}$-acid glycoprotein is the major component of the seromucoid fraction of normal serum, the change in blood concentration of this protein is reflected in this fraction. However, since the seromucoid fraction (33) contains other $\alpha_{1^{-}}, \alpha_{2}-$, and $\beta$-globulins, including the haptoglobins, and since some of these proteins are also increased in their blood level under certain stress conditions, although probably at different rates, the change in concentration of the total seromucoid fraction may show the same trend as that of $\alpha_{1}$-acid glycoprotein, but need not be proportional. To obtain reliable data on its level, we measured the seromucoid fraction in terms of both the content of its total neutral hexoses and polypeptide moiety. Further, it should be noted that in the normal state an increase in the protein-bound serum hexoses was found with increasing age, whereas no sex difference could be observed (34-36). This difference due to age may account for at least part of the observed difference in the seromucoid and $\alpha_{1}$-acid glycoprotein levels between the two groups studied. The average age of the individuals undergoing surgery was 75 , whereas that of the pregnant women was 26 . The seromucoid fraction of Japanese normal adults has been reported to be about that of Caucasians (37) in the same age group.

\section{Summary}

$\alpha_{1}$-Acid glycoprotein was isolated in homogeneous form from sera of apparently healthy Caucasian adults who underwent a major operation, of pregnant Japanese women, and, as controls, of other normal Caucasian adults. The type of the $\alpha_{1}$-acid glycoprotein variant of each individual remained constant during the period of investigation in spite of the temporary large increase in the blood level of this protein in those individuals who were subjected to stress. The sialic acid content of all $\alpha_{1}$-acid glycoprotein preparations was constant $(11 \%)$ and identical with that of pooled normal $\alpha_{1}$-acid glycoprotein. It should be emphasized that these preparations include all three $\alpha_{1}$-acid glycoprotein variants. The change in blood concentration of this protein was measured directly by isolating this protein in homogeneous form and indirectly by determining the level of the seromucoid protein fraction of which $\alpha_{1}$-acid glycoprotein is the major component. The results obtained support the concept that the structure of $\alpha_{1}$-acid glycoprotein is genetically determined.

\section{Acknowledgments}

We wish to express our thanks to Drs. S. Roseman and G. W. Jourdian, University of Michigan, Ann Arbor, for their generous gift of highly purified neuraminidase. We would also like to thank Miss Käthi Hunziker and Miss Alice Scholz for valuable technical assistance.

\section{References}

1. Winzler, R. J. Glycoproteins and glycosaminoglycans in plasma and in some other body fluids in The Amino Sugars, E. A. Balazs and R. W. Jeanloz, Eds. New York, Academic Press, 1965, vol. 2A, p. 337.

2. Greenspan, E. M. Clinical significance of serum mucoproteins. Advanc. intern. Med. 1955, 7, 101.

3. Jayle, F.-M. Les Haptoglobins-Etudes Biochimique, Genetique, et Physiopathologique. Paris, Masson, 1962.

4. Doležalová, V., and Z. Brada. Host-tumor relationship. XVII. Quantitative changes in some fractions of sulphosalicylic acid soluble substances in the serum and ascites fluid of Yoshida ascites tumour bearing rats. Neoplasma (Bratisl.) 1964, 11, 459.

5. Schmid, K. Methods for the isolation, purification and analysis of glycoproteins-a brief review. Chimia 1964, 18, 321.

6. Schmid, K. Preparation and properties of serum and plasma proteins. XXIX. Separation from hu- 
man plasma of polysaccharides, peptides and proteins of low molecular weight. Crystallization of an acid glycoprotein. J. Amer. chem. Soc. 1953, 75, 60.

7. Schmid, K., J. P. Binette, S. Kamiyama, V. Pfister, and S. Takahashi. Studies on the structure of $\alpha_{1}$-acid glycoprotein. III. Polymorphism of $\alpha_{1}$-acid glycoprotein and the partial resolution and characterization of its variants. Biochemistry 1962, 1, 959.

8. Weimer, H. E., J. W. Mehl, and R. J. Winzler. Studies on the mucoproteins of human plasma. $\mathrm{V}$. Isolation and characterization of a homogeneous mucoprotein. J. biol. Chem. 1950, 185, 561.

9. Chandler, A. M., and O. W. Neuhaus. Synthesis of serum glycoproteins in response to injury. Amer. J. Physiol. 1964, 206, 169.

10. Winzler, R. J. Metabolism of glycoproteins. Clin. Chem. 1965, 11, 339.

11. Schmid, K., K. Tokita, and H. Yoshizaki. The $\alpha_{1-}$ acid glycoprotein variants of normal Caucasian and Japanese individuals. J. clin. Invest. 1965, 44, 1394.

12. Schmid, K., J. P. Binette, K. Tokita, L. Moroz, and H. Yoshizaki. The polymorphic forms of $\alpha_{1}$-acid glycoprotein of normal Caucasian individuals. J. clin. Invest. 1964, 43, 2347.

13. Schmid, K., M. B. MacNair, and A. F. Bürgi. The chromatographic separation and purification of acidic proteins on carboxylated ion exchange resins. J. biol. Chem. 1958, 230, 853.

14. Cassidy, J. T., G. W. Jourdian, and S. Roseman. The sialic acids. VI. Purification and properties of sialidase from Clostridium perfringens. J. biol. Chem. 1965, 240, 3501.

15. Winzler, R. J. Determination of serum glycoproteins in Methods in Biochemical Analysis, D. Glick, Ed. New York, Interscience, 1955, vol. 2, p. 279.

16. Warren, L. The thiobarbituric acid assay of sialic acids. J. biol. Chem. 1959, 234, 1971.

17. Svennerholm, L. Quantitative estimation of sialic acids. II. A colorimetric resorcinol-hydrochloric acid method. Biochim. biophys. Acta (Amst.) 1957, 24, 604.

18. Smithies, O. An improved procedure for starch-gel electrophoresis: further variations in the serum proteins of normal individuals. Biochem. J. 1959, $71,585$.

19. Ouchterlony, Ø̋. Diffusion-in-gel methods for immunological analysis in Progress in Allergy, $P$. Kallós and B. H. Waksmann, Eds. Basel and New York, S. Karger, 1962, vol. 6, p. 30.

20. Neuhaus, O. W., and A. Liu. Biochemical significance of serum glycoproteins. III. Hepatic production of $\alpha_{1}$ and $\alpha_{2}$ globulins responding to injury. Proc. Soc. exp. Biol. (N. Y.) 1964, 117, 244.

21. Neuhaus, O. W., H. F. Balegno, and A. M. Chandler. Biochemical significance of serum glycoproteins. I. Changes in rat serum following injury. Proc. Soc. exp. Biol. (N. Y.) 1961, 107, 960.
22. Björnesjö, K. B., I. Werner, and L. Odin. The influence of surgery on serum and urine hexosamine, serum mucoprotein, glutamic-oxaloacetic transaminase (Got), and C-reactive protein. Scand. J. clin. Lab. Invest. 1959, 11, 238.

23. Williamson, M. B., L. DiLallo, and H. B. Haley. Serum glycoprotein levels during wound tissue regeneration. Clin. Chem. 1963, 9, 274.

24. Mansfield, R. E., and M. R. Shetlar. Serum glycoprotein changes in pregnancy. Proc. Soc. exp. Biol. (N. Y.) 1963, 112, 891.

25. Mack, H. C. The Plasma Proteins in Pregnancy. A Clinical Interpretation. Springfield, Ill., Charles C Thomas, 1955.

26. Kelleher, P. C., and C. A. Villee. A protein present in fetal but not in maternal rat serum. Science 1962, 138, 510 .

27. McNeil, C., C. R. Berrett, L. Y. Su, E. F. Trentelman, and W. M. Helmick. Sialic acid as a measure of serum mucoproteins. Amer. J. clin. Path. $1965,43,130$.

28. Decker, B., W. F. McGuckin, B. F. McKenzie, and C. H. Slocumb. A study of some "acute phase reactants" in rheumatic diseases. Arth. and Rheum. 1960, 3, 49.

29. Saint-Cyr, C. de V., H. Clève, and P. Graber. Identification et dosage de certains constituants antigéniques dans les extraits perchloriques de sérums humains normaux et pathologiques. Rev. franç. Etud. clin. biol. 1960, 5, 776.

30. Easton, J. A., J. Hardwicke, and P. H. Whitehead. The estimation of two alpha ${ }_{1}$ glycoproteins (orosomucoid and another alpha ${ }_{1}$ acid glycoprotein) in health and disease. J. clin. Path. 1962, 15, 585.

31. Robert, B., C. de V. St. Cyr, L. Robert, and P. Grabar. Etude comparative par immunoélectrophorèse et par polarographie des extraits trichloroacetique et perchlorique du serum humain normal. Clin. chim. Acta 1959, 4, 828.

32. Kalous, V. Polarographische Bestimmung des Mucoproteins MP-1 nach der Trennung der Sera durch Papierelektrophorese. Coll. Czech. chem. Commun. 1960, 25, 878.

33. Schultze, H. E., K. Heide, and H. Haupt. Die mit Perchlorsäure nicht fällbaren Proteine des Humanserums. Clin. Chim. Acta 1962, 7, 854.

34. Pearce, R. H., E. M. Watson, R. Stodolski, J. M. Mathieson, and J. J. Theoret. Effects of age and sex on the electrophoretic fractions of the serum glycoprotein. Clin. Chem. 1964, 10, 1066.

35. Böttiger, L. E., and G. Sterky. Serum proteins and glucoproteins in normal schoolchildren. Acta med. scand. 1962, 172, 339.

36. Böttiger, L. E., and A. Holmström. Serum proteinbound carbohydrates in normal women. J. Lab. clin. Med. 1964, 63, 772.

37. Ito, R., and T. Richu. Clinical significance of estimation of serum mucoprotein in various diseases, especially peptic ulcer and malignant tumor. Tohoku Igaku Zasshi 1962, 65, 127. 